\title{
LOSONCZ Miklós
}

\section{SZERVEZETI SÚLYKÉPZÉS \\ A MAGYAR GAZDASÁGPOLITIKÁBAN}

A kis és közepes méretű vállalkozások ösztönzése minden ország gazdaságpolitikájában előkelő helyen szerepel. Ez a tanulmány a kérdést szélesebb összefüggésrendszerbe ágyazva, a szervezeti súlyképzés fogalma köré csoportosítva tárgyalja. Arra a kérdésre keresi a választ, hogy mi lehet a szerepe a nagyvállalatoknak és a kis és közepes méretű cégeknek Magyarország gazdasági fejlődésében, és e szerep érvényesítéséhez milyen gazdaságpolitikai lépésekre van szükség. A tanulmány először a szervezeti súlyképzés közösségi feltételrendszerét, a súlyképzést közvetlenül és közvetve befolyásoló közösségi jogszabályokat tekinti át, majd a magyarországi vállalatszervezeti struktúra áttekintése és elemzése alapján a gazdaságpolitikával szembeni követelményeket határozza meg.

Az Európai Unióban nincs olyan jogszabály, közös vagy közösségi politika, amely kifejezetten a gazdaság szervezeti rendszerének befolyásolására, szervezeti súlyképzésre irányul. E mögött az az elméleti álláspont is meghúzódhat, amely szerint nincs olyan optimális vállalati szervezeti struktúra, amelynek létrehozására nemzetállami vagy közösségi szinten célszerű lenne törekedni.

Az egyes országok eltérő sajátosságai mellett ez azzal is magyarázható, hogy a világgazdasági fejlődés különböző szakaszai a gazdasági növekedés hajtóerőinek függvényében más és más követelményeket támasztanak a vállalatszervezeti rendszerrel szemben mind nemzetgazdasági, mind ágazati szinten. Olyan időszakban, amikor a világgazdasági növekedés hajtóerejét a kutatás-fejlesztésigényes, illetve a méretgazdaságossági megtakarításokra érzékeny, szériaigényes ágazatok (gépjárműipar, háztartási tartós fogyasztási cikkek stb.) képezik, a nagyvállalatok szerepe domborodik ki. A kis sorozatú, az exkluzivitás érzetét keltő termékek és szolgáltatások iránti kereslet dinamikus bővülése viszont a kis és a közepes méretű vállalatokat hozza kedvezőbb helyzetbe. A valóságban a különböző méretkategóriájú vállalatok közötti összefüggések árnyaltabbak. Az egyes országok vállalati szervezeti rendszere ráadásul hosszabb történelmi fejlődés eredménye, radikális változtatásokra kevés a lehetőség.

Az Európai Unióban a versenypolitikával és a versenyjoggal kapcsolatos szabályozás és a vállalkozás- ösztönzési politika gyakorolhat hatást a vállalati szervezeti rendszerre és méretstruktúrára. A közösségi versenyjog amellett, hogy tiltja a versenykorlátozó megállapodásokat és a gazdasági erőfölénnyel való visszaélést, utólag ellenőrzi a vállalati koncentrációt. Bizonyos paraméterek elérése esetén a Bizottság előzetes engedélyét kell kérni a vállalati fúziókra ${ }^{1}$. „Közösségi méretű" egy tranzakció (vállalkozások egyesülése, más vállalatok feletti irányítás megszerzése) akkor, ha az érintett cégek együttes éves forgalma több mint ötmilliárd euró, és a vállalatcsoportnál legalább két cég forgalma 250 millió eurónál nagyobb az Európai Unión belül. Nincs utólagos bizottsági ellenőrzés akkor, ha az érintett vállalatoknak az Európai Unión belüli teljes forgalmuk több mint kétharmada ugyanabból a tagállamból származik. Kisebb méretű vállalkozásokat is érinthetnek a vállalati koncentrációk ellenőrzésére vonatkozó közösségi jogszabályok akkor, ha az éves világforgalmuk eléri a 2,5 milliárd eurót, emellett a Közösségen belüli forgalmuk egyenként, illetve együtt véve eleget tesz még egy sor összeghatárnak. Ezek a rendelkezések nagyságrendi összefüggések miatt csak akkor érintik Magyarországot, ha ide betelepült külföldi nagyvállalatok hajtanak végre fúziót vagy vállalatátvételt.

A közösségi versenyjog általános szabályként tiltja állami támogatás nyújtását. A kis jelentőségű állami támogatásokkal kapcsolatban vezettek be az EU-ban csoportmentességet 2000-ben a kis- és közepes méretű 
vállalatok számára és a képzési támogatás terén. Ekkor fogadták még el a de minimis szabályt, amely azt mondja ki, hogy a bármely vállalatnak nyújtott, három év alatt százezer eurót meg nem haladó támogatás nem minősül olyan támogatásnak, amiről a Bizottságot tájékoztatni kell. Ez utóbbival összefüggésben a $\mathrm{Bi}-$ zottság abból indul ki, hogy ha egy-egy vállalatnak 50100 ezer euró támogatást juttatnak, akkor az nem torzítja el a versenyt a tagországok között és nem érinti a tagállamok közötti kereskedelmet. Ha tehát a támogatás nem haladja meg az ötvenezer eurót, illetve három éven keresztül a százezer euró küszöbérték alatt marad, és nem zavarja meg a tagállamok közötti kereskedelmet, akkor az nem tekinthető állami támogatásnak, ennélfogva nem is kell bejelenteni a Bizottságnak. Ugyanakkor egy vállalat elvileg beruházási, kutatásfejlesztési valamint műszaki, gazdasági és beruházási tanácsadás céljából is igénybe vehet támogatást, mert a kis- és közepes méretű vállalatoknak juttatott támogatások legálisan kumulálhatók. Szintén kumulált szubvencióban részesülhet kis vagy közepes méretű vállalkozások alapítása gazdaságilag elmaradott területeken.

A befektetések ösztönzését szolgáló fejlesztési támogatások szintén nem a nagyvállalati szektort preferálják. (Az adókedvezmény az EU-ban állami támogatásnak minősül, ezért vonatkozik rá a közösségi versenyjog.) Az ún. támogatásintenzitás értéke, amely azt mutatja meg, hogy adott beruházás hány százalékát veheti igénybe maximálisan egy vállalat adókedvezmény formájában, sávosan változik, bizonyos sávokat átlépve a beruházott összeg mind kisebb hányada igényelhető vissza, azaz a kisebb összegű beruházások, amelyeket nagy valószínűséggel, bár nem szükségszerűen kis és közepes méretű vállalatok hajtanak végre, nagyobb kedvezményben részesülnek, mint a nagyberuházások.

A közösségi versenypolitika és versenyjog abból indul ki, hogy a verseny a gazdasági növekedés motorja. A közösségi versenyjog és versenypolitika célja ezért a verseny előtti akadályok lehetőség szerinti lebontása, a versenymechanizmusok minél erőteljesebb kibontakoztatása. A jelek szerint a versenymechanizmusok kibontakoztatását leginkább a piaci szereplők számának növelésével, a monopol- és oligopol piaci struktúrák megszüntetésével, illetve gyengítésével, a kis és közepes méretű vállalatok mozgásterének tágításával lehet érvényesíteni. Ezért nem meglepő, hogy a vonatkozó közösségi jogszabályok közvetlenül és közvetve a kis- és középvállalati szektort preferálják a nagyvállalatokkal szemben.

A kis és közepes méretű vállalkozásoknak az ismertetetten túlmenő ösztönzésére az 1980-as évtized közepétől fordítanak figyelmet az EU-ban. Mind közösségi szinten, mind az egyes tagállamokban elfogadták azt a megközelítést, hogy az államnak és az önkormányzatoknak segítséget kell nyújtaniuk a kis és közepes méretű cégeknek a nagyvállalatokkal szembeni versenyhátrányok kiegyenlítéséhez. Figyelmet érdemel, hogy nincsenek nagy különbségek a tagállamok, illetve az EU kis- és középvállalati politikájának cél- és eszközrendszerében.

A lisszaboni stratégia nagy fontosságot tulajdonít a kis és középvállalati szektornak. Ezt azzal indokolja, hogy ez a szféra új munkahelyek forrása, üzleti ötletek melegágya és a vállalkozások hajtóereje. Ebben a szférában az „először gondolkodj kicsiben” elv alapján nagy számú, később a nagyvállalatoknál is alkalmazható elképzelés tesztelhető.

A vállalkozásösztönzés része a Kisvállalkozások európai chartája címú, jogilag nem kötelező dokumentum, amely a következő célkitűzéseket tartalmazza:

- kisvállalkozók oktatása,

- KKV-barát szabályozás: lehető legkisebb adminisztratív és szabályozási terhek,

- olcsóbb és gyorsabb vállalkozásalapítás,

- technológiai kapacitások javítása,

- a belső piac előnyeinek kiaknázása,

- e-business, on-line hozzáférés.

Ezen túlmenően hétéves közösségi programokat is kidolgoztak. A 2001 és 2005 közötti időszakra vonatkozó VI. Többéves Vállalat- és Vállalkozásfejlesztési Program céljai a következők ${ }^{2}$ :

- a vállalkozások versenyképességének és növekedési potenciáljának fokozása,

- a vállalkozói szellem előmozdítása,

- a vállalkozások adminisztratív és szabályozási környezetének egyszerűsítése,

- a kis- és középvállalkozások pénzügyi helyzetének javítása,

- a közösségi támogató szolgáltatások, programok igénybevételének megkönnyítése, a koordináció javítása.

Ezek a célkitűzések csak részben újak. A leglényegesebb változás az, hogy a program a piachelyettesíto támogatások helyett a szabályozási környezet egyszerűsítésével és a támogató szolgáltatások fejlesztésének előmozdításával kívánja jobb helyzetbe hozni a kis- és középvállalkozásokat (Borbás László 2003, 230. o.). A program forrásfedezete összesen 450 millió euró (évi 90 millió euró).

A 2000 és 2006 közötti költségvetési periódusban a közösségi költségvetésben a Strukturális Alapok forrá- 
saiból 16 milliárd eurót (az összes forrás 11 százalékát) irányoztak elő kis- és középvállalatokhoz kapcsolódó projektekre. Emellett a 2002 és 2006 közötti időszakra szóló 6. Kutatás- és Technológiafejlesztési Programban 2,2 milliárd euró szerepel a kis- és középvállalati szektor kutatási és innovációs támogatására.

Mind a lisszaboni stratégia, mind a Kisvállalkozások európai chartája, mind pedig sok egyéb program az általánosságok, pontosabban a retorika szintjén támogatja a kis és középvállalati szektort. A kitűzött célokhoz azonban nem rendelnek megfelelő nagyságrendű közösségi forrásokat. Az EU kibővülése előtt a Strukturális Alap forrásaiból éves szinten 125 euró jutott egy vállalatra a 15 tagú Európai Unióban. Az utóbbi tíz évben a 15 tagú Európai Unióban működő kis és közepes méretű vállalatoknak mindössze 1 százaléka részesült támogatásban közösségi KKV-program keretében. A nagyvállalatokat diszpreferáló közösségi jogi szabályozás és a közösségi szintű kis- és középvállalati ösztönzés viszonylag csekély forrásfedezete közötti aránytalanságból az a következtetés is levonható, hogy EU-ban a jogszabályi környezetet teremtették meg a vállalkozásfejlesztéshez, az ehhez szükséges forrásfedezetet pedig a tagállamoknak kell elsősorban előteremteniük, a közösségi források erősen kiegészítő jellegűek.

\section{A vállalatszervezet sajátosságai Magyarországon}

Magyarországon a Központi Statisztikai Hivatal adatai szerint 2003-ban 882 ezer vállalkozás működött (KSH, 2004: 286. o.). Ebből mindössze 9802 vállalkozás foglalkoztatott 20-49 főt, 4898 cég 20-249 fót és 979 vállalat 250 főnél többet. A vállalkozások 98,2 százalékának 20 főnél kevesebb foglalkoztatottja volt. A kis és közepes méretű vállalkozások jelentős része nem piaci alapon múködik, hanem kényszervállalkozás. Erre is utal az a körülmény, hogy 2003-ban a működő vállalkozások 62 százalékának nem volt bejelentett alkalmazottja ${ }^{3}$. A több mint nyolcszázezer mikroés kisvállalkozás irdatlan tranzakciós költséget generál a nemzetgazdaság egésze számára, és megoldhatatlan feladat elé állítja az APEH-et ${ }^{4}$. A jövedelem-eltitkolás lehetősége lehetetlenné teszi, de legalább is akadályozza a kis- és középvállalatok közötti kooperációt. Emiatt a szektor banki és tőkepiaci finanszírozása is nehéz.

A szervezeti súlyképzés szempontjából a kis- és középvállalati szegmens a lényeges, a mikro- és az álvagy kényszervállalkozások figyelmen kívül hagyhatók, mert ebben a csoportban a fejlesztés és a növekedés egyáltalán nem kézenfekvő probléma. Emellett a mikro- és a kényszervállalkozások nehézségek nélkül működhetnek a kereskedelemben és nagyszámú szolgáltató ágazatban és alágazatban (ingatlan- stb. szolgáltatás), a dolog természeténél fogva nem indokolt tőlük exportot és kutatás-fejlesztést várni. A szervezeti súlyképzéssel kapcsolatos gondolatmenetet ezért a továbbiakban a feldolgozóipari vállalatokra célszerü összpontosítani.

A kis- és középvállalkozások a magyar GDP 45 százalékát állítják elő, miközben a magángazdaságban foglalkoztatottak 60 százaléka (több mint 1,5 millió fő) jut rájuk. A jelentős foglalkoztatási funkció miatt a kis és közepes méretű vállalatok kiemelkedő szerepet játszanak a lisszaboni stratégia foglalkoztatási célkitűzéseinek megvalósításában (a foglalkoztatási ráta a foglalkoztatottak aránya a gazdaságilag aktív népességben — 70 százalékra történő emelése 2010-ig). A hazai kis- és középvállalati szektor termelékenységének nagyvállalatokéhoz viszonyított lemaradása nagyon jelentős, lényegesen nagyobb az Európai Unióban tapasztalhatónál. A magyar kisvállalkozások nagyvállalatokhoz viszonyított termelékenysége mintegy a fele, a közepes vállalatoké pedig kétharmada az európai uniós átlagnak (GKM-OM-IHM, 2003: 24. o.). Az egyéni és családi megtakarításokból induló kisvállalkozások néhány millió forint alaptőkéje nem elegendő technológiai korszerűsítésre és piaci innovációra. Ezek a cégek nemigen tudják előteremteni azt a 20-40 millió forintot sem, amely a kisvállalati méretekben is standard minőségű rugalmas árutermelés megalapozását célzó beruházás forrásigénye.

A feldolgozóiparban különösen aggasztó a középvállalatok kis száma, amely ráadásul alig nőtt 2001 és 2004 között. Kiegyensúlyozatlan szerkezetre enged következtetni az a körülmény, hogy például a közel ötven gép- és berendezésgyártó nagyvállalat mellett mindössze 210 közepes méretű cég működik. A villamosgép- és műszergyártás több mint száz nagyvállalata mellett csak 191 közepes méretű vállalat van. A vegyipar szerkezete is hasonló, 44 nagyvállalatra 59 közepes cég jut

A kis- és középvállalatok szerepe ugyanakkor kiemelkedő a foglalkoztatottságban. A kényszervállalkozások nagy száma miatt azonban az itt lévő munkahelyek sokkal instabilabbak, mint a nagy szervezeteknél. A keresetek is sajátos differenciálódást mutatnak, minél kisebb egy szervezet, annál alacsonyabb a kereset, ami viszont a fekete vagy szürke gazdaság jelenlétére is utalhat.

Egy 2003-ban készült tanulmány szerint az azonos ágazatban, hasonló vállalati méretek mellett a külföldi tulajdonú vállalatoknál két és félszer annyi a fizetés, mint a magyar cégeknél. A tőkeerősebb külföldi hát- 
terű vállalatok kisebb mértékben élnek az ,adóoptimalizálás" vagy adókikerülés lehetőségeivel, így a papíron, minimálbéren történő vagy részmunkaidős foglalkoztatással, illetve az alkalmazottaik kényszervállalkozásba való terelésével. Egy 2002. évi osztrák felmérés szerint az egy főre jutó bérköltségekben viszonylag kis különbség volt a kis- és a nagyvállalatok között. Az ezer főnél többet foglalkoztató vállalatok foglalkoztatottainak a keresete átlagosan 35 százalékkal haladta meg a kis szervezetekéit, ami összhangban van a normál piaci viszonyokkal. A vállalati méretekhez kötődő különbség Magyarországon is 40 százalékon belüli. A határvonal a hazai és a külföldi vállalatok között van. Ezt nem csekély mértékben magyarázhatja az, hogy a gyengébb tőkeellátottság és az alacsonyabb termelékenység miatt a hazai vállalkozások fennmaradását veszélyeztetné, ha a külföldi cégekre jellemző magas keresetekhez kapcsolódó terheket is meg kellene fizetniük 5

A szektor sajátosságaiból és a gazdaságban elfoglalt szerepéből is következik, hogy a magyar kis- és középvállalkozások exportáló képessége alacsony, a kivitelnek mindössze 8-10 százalékát adják, tehát döntően a hazai piacon értékesítenek, ami - az exportorientált nagyvállalatoktól eltérően - korlátozza növekedési lehetőségeiket. Emellett van bizonyos közvetett export, exportőr nagyvállalatoknak történő beszállításon keresztül.

A kis és közepes méretű vállalatok árfolyamváltozásoknak való kitettsége kiemelkedő mértékű. A tranzakciós árfolyamkockázat, amelynek forrása konkrét üzlet, kevéssé jellemző, tekintettel a vállalati szegmensnek a nemzetközi munkamegosztásba való bekapcsolódása alacsony színvonalára. A gazdasági kitettség, amely a devizaárfolyamok mozgása miatt a cég versenyképességében, illetve a cég értékelésében bekövetkező változás kockázata, akkor is jelentkezhet, ha a vállalatnak semmilyen devizaügylete sincs (Érsek Zsolt, 2002: 58. oldal). Például a forint felértékelődése a dollárral vagy az euróval szemben olyan olcsóvá teheti a behozatalt, hogy a tisztán hazai piacra, hazai alapanyagból termelő vállalat is piacot veszíthet.

Az Európai Unióban már megjelent a tartós életképesség igazolása. A tartós életképesség fogalmába a minőségirányítás és a környezetközpontú vállalatirányítási rendszerek mellett beletartozik a vállalat életképességének bizonyítása is gazdasági szempontból. Az EU-ban bejegyzett vállalatok olyan partnerekkel kívánnak tartós üzleti kapcsolatokat kiépíteni, amelyek nem tủnnek el egyik napról a másikra a piacról. Ennek a követelménynek a magyar kis- és középvállalati szféra viszonylag kevés szervezete képes eleget tenni.
A kis- és középvállalati szegmensben a vállalati életképességet célszerú kicsit részletesebben is elemezni. Ha feltételezzük, hogy a vállalkozó ért a racionális gazdálkodáshoz és józan kockázatvállaló képességgel is rendelkezik, akkor a piaci és gazdaságpolitikai feltételek döntik el azt, hogy a vállalkozás életképes lesz-e vagy nem. Az életképességnek három tartománya különböztethető meg: az életben maradási képesség, amely csupán a költségek megtérülését és a tulajdonos megélhetését biztosítja, a lépéstartási képesség, amikor a megtermelt nyereség elegendő a megszerzett piaci pozíciók megtartására, végül az expanziós képesség, amikor a vállalat rendszeresen számíthat az elvárt haszonszintet érezhetően meghaladó jövedelmezőségre (Kozma Ferenc, 2001: 44-45. o.). E megközelítésben legalább ötszázezer szervezetre az életben maradási képesség a jellemző, míg egészen szűk az expanziós képességgel rendelkező magyarországi vállalkozás.

\section{A szervezeti súlyképzéssel szembeni követelmények}

Magyarországon a gazdaságpolitika hagyományosan elhanyagolt és elnagyolt területe a szervezeti súlyképzés, azaz annak a kérdésnek az egyértelmű megválaszolása, hogy a szervezeti diverzifikációt kell-e ösztönözni, 800-900 ezer kisvállalkozás támogatásával, vagy a nemzetközi vállalatgazdasági integrációba való bekapcsolódás, a szervezeti súlyképzés a célszerű stratégia a nagyvállalatok preferálásával.

A kis- és középvállalati szektor, illetve a nagyvállalati szféra ösztönzésére szolgáló eszközrendszer gyökeresen eltér egymástól. A két stratégia követelményei nehezen vagy legfeljebb szűk tartományban egyeztethetők össze egymással. A kisvállalkozások ösztönzése az erőforrások decentralizálását, a kis tőkeigényű, rendszerint kevéssé technológiaigényes ágazatok, alágazatok, tevékenységek preferálását jelenti. A nagy szervezetek dominanciájára építő stratégia az erőforrások koncentrálását, a nagy, a közepes és a kis szervezetek közötti vertikális integráció erősítését sürgeti.

A stratégia megválasztásában igen nagy szabadságfokkal rendelkezik a magyar gazdaságpolitika, közösségi jogszabályok és politikák nem kötik meg a kezét. Nagyfokú leegyszerúsítés lenne tágan értelmezett költségvetési-államigazgatási költség-haszon elemzés alapján dönteni a súlyképzésről. Ebből a mérlegelésből nagy valószínűséggel egyértelműen a nagyvállalati szféra kerülne ki győztesen, hiszen ugyanakkora anyagi, szervezeti, szellemi stb. ráfordítás jóval nagyobb 
hozamot eredményezne ebben a szegmensben, mint a kis- és középvállalatiban.

A magyar gazdaság növekedési ütemét és nemzetközi versenyképességét meghatározó mintegy 6000 közepes és nagyvállalat sajátosságainak megfelelő ösztönzőrendszer kidolgozása és érvényesítése irányítástechnikai szempontból könnyebb, mint egy olyan vállalkozásösztönzési rendszeré, amely közel 900 ezer vállalkozás körülményeit, érdekviszonyait veszi figyelembe.

Magyarországon a gazdasági fejlődéshez, a nemzetközi munkamegosztásba való hatékony bekapcsolódáshoz, a nemzetközi versenyképesség javításához több évtizedes perspektívában a magyar stratégiai érdekeket szolgáló nagyvállalatok hálózatára van szükség. Ezért a nagyvállalatok, azok közül is a külföldi érdekeltségű nagyvállalatokra támaszkodó szervezeti súlyképzés célszerű. A csoport nem elsősorban preferálást és támogatást igényel, hanem átlátható szabályozást, korrekt gazdasági kormányzást, kiszámítható környezetet. Ez a stratégia biztosítja leginkább a múszakistrukturális korszerűsödés és az exportkapacitások növelésének kívánatos ütemét. A kis- és középvállalati szektor hasznosságának és sikerességének is ez a feltétele. Ez a szegmens fontos motorja a növekedésnek, de ha csak erre épít a gazdaságpolitika, akkor az átlagok ugyan javulnak, de a gazdaság duális jellege megmarad, sőt erősödik. Az a veszély is fennáll, hogy kevés számú, a magyar gazdaságba be nem ágyazódott külföldi nagyvállalat kivonulása számottevő mértékben érintheti a makrogazdasági folyamatokat (a GDPés az ipari termelés dinamikája stb.).

A nagyvállalatok, azok közül is a külföldi részesedésű cégek esetében van leginkább lehetőség a termelékenység javítására, következésképpen a nagyvállalati szféra termelékenységének növekedési üteme határozza meg a magyar reálbérek európai uniós átlaghoz való felzárkózásának ütemét. A forint euróval szembeni reálárfolyama (azaz a nominális árfolyamnak a magyar és az EU valamilyen árindexszel - fogyasztói, termelői vagy egységnyi bérköltség - mért hányadosával kiigazított értéke) tartósnak tekinthető felértékelődését is a nagy szervezetek tudják hatékonyabban kezelni, mint a kicsik. A nagy fokú gazdasági kitettség miatt azonban a reál-felértékelődés kockázatával ettől függetlenül a kis szervezeteknek is foglalkozniuk kell. Ez arra hívja fel a figyelmet, hogy össze kell hangolni az euró bevezetését és a szervezeti súlyképzést, azon belül a kis és közepes méretű vállalatok ösztönzését egymással.

A jelek szerint a kormány eddig is érvényesített szervezeti súlyképzést, méghozzá a nagyvállalatokat preferálót. A támogatások költség-haszon egyenlege egyértelműen kedvezőbb a nagyvállalatoknál, mint a kis- és középvállalkozásoknál. Sajtóinformációk szerint 2004-ben 4800 kis- és középvállalat 12 milliárd forint állami támogatásból több mint harmincmilliárd forint fejlesztést valósított meg (40 százalékos támogatási arány, 2,5-szeres szorzó). Ezzel szemben 2000 és 2004 között 31 milliárd forint támogatás 184 milliárd forint értékủ beruházást indukált ${ }^{6}$ (17 százalékos támogatási arány, hatszoros szorzó).

A nagy szervezetek javára történő súlyképzés, mint gazdasági racionalitás ellentmondásba kerülhet a politikai racionalitással, a kis- és középvállalati szektor tulajdonosai és alkalmazottai ugyanis minimálisan másfél-kétmillió szavazót képviselnek. Részben ezért, részben gazdasági megfontolásokból a nagyvállalatokra koncentráló súlyképzés feltétlenül kiegészítendő a kis- és középvállalati szektorra vonatkozó stratégiával. A KKV-szektoron belül is súlyképzésre van szükség, a kis- és középvállalati stratégia középpontjába a lépéstartási és expanziós képességgel rendelkező vállalati kört célszerű állítani, az ösztönzőrendszert erre a szegmensre célszerű kalibrálni. Ennek központi eleme lehet a nagyvállalati szféra és a kis- és középvállalati szektor közötti vertikális és horizontális kapcsolatok erősítése. Ennek eszközei közé tartozik a szegmens ellátása tőkével, beleértve a kockázati tőkét, menedzsment- és marketingtudással, műszaki és piaci információkkal. A közösségi transzferek mellett a közösségi jog által lehetővé tett nemzeti támogatásokat (de minimis szabály) ebbe a szegmensbe célszerű terelni, itt hasznosulnak a legjobban. A befektetés-ösztönzéssel kapcsolatos beruházási fejezetben tárgyalt beruházási adókedvezmény szintén a kisebb beruházásokat preferálja, ami inkább a közepes vállalatoknak kedvez, legalább is a közepes méretű vállalatok is igénybe tudják venni a kedvezményt.

Az életben maradási képességgel rendelkező vállalati-vállalkozói kör esetében minimális szintű támogatás nyújtása célszerû. A stratégia súlypontja a nem önálló foglalkoztatás ösztönzése kell, hogy legyen, a nagyvállalati szektorban. Nemzetközi tapasztalatok alapján a nem önálló foglalkoztatás terjedése kedvezően érinti a termelékenység növekedését, azaz a nagyobb szervezetekben több lehetőség van a termelékenység emelésére, mint a kicsikben. A nagyvállalatoknál kisebb az adóelkerülés, a gazdaság kifehérítésére vonatkozó törekvésekkel is a nagy szervezetek preferálása, az ott történő foglalkoztatás ösztönzése van összhangban. A talpon maradó törpevállalkozások a helyi piacokon jelentkező áru- és szolgáltatáskeresletet elégíthetik ki. 
A stratégia első pillére, a visszafejlesztés már részben spontán módon - megkezdődött a minimálbér sorozatos emelésével, a második pillér, a foglakoztatás növelése a nagyvállalati szektorban még sok kívánnivalót hagy maga után. 2001 tavaszán a minimálbéresek 15-20 százaléka 5 főnél, nagyjából 60 százaléka 20 főnél, hozzávetőlegesen 70 százaléka pedig 50 főnél kevesebbet foglalkoztatott vállalatnál dolgozott (Kertesi Gábor - Köllő János, 2004). A képzetlen munkaerő iránti kereslet az átlagosnál rugalmasabb. Kertesi Gábor és Köllő János számításai szerint 2001-ben a kisvállalati szektorban mintegy 12 ezer állás szűnt meg, elsősorban azokban a térségekben, ahol magas volt a munkanélküliség annak hatására, hogy a minimálbér átlagbérhez viszonyított aránya a 2000. évi 29ről 2002-ben 43 százalékára ugrott. A kisvállalkozások támogatására alakult, egyébként rendkívül szétforgácsolt és alacsony hatékonysággal, nagy adminisztrációval múködő szervezetek, alapítványok stb. nem tudták kompenzálni a foglalkoztatás csökkenését.

A szervezeti súlyképzés jegyében célszerű felülvizsgálni a vállalatalapítás feltételeit. A korlátolt felelősségű társaságok alapítására törvényben meghatározott minimálisan hárommillió forint tőkeigény egyrészt messze nem elegendő ahhoz, hogy hatékony korlátot állítson a vállalkozássá válás elé. A törvényben előírt összeg könnyen előteremthető. Másrészt a hárommillió forint minimális alaptőke-követelmény nem elegendő a vállalkozásokkal kapcsolatban álló fogyasztók, bankok, szállítók stb. érdekeinek képviseletére sem. A hárommillió forint alaptőkéjű társaságok csak fedezet felajánlása mellett jutnak hitelhez, a szóban forgó vállalatok részvételével nagy volumenű ügyletek lebonyolítása kockázatos stb. A szervezeti súlyképzés előmozdítása érdekében a korlátolt felelősségú társaságok minimális alaptőkéjét a jelenlegi hárommillió Ft-ról legalább ötmillió forintra kellene emelni. Ezen intézkedés nyomán várható, hogy javul a piaci alapon működő kis- és középvállalati szektor életképessége, ezzel összefüggésben a külső érintettek biztonsága.

A kis- és középvállalati szféra hosszabb távon és sokszor áttételesen a közösségi versenypolitikából és versenyjogból is profitálhat. Miként az a korábbi áttekintésből kitűnik, a közösségi versenyjog egyrészt gátat szab a szervezeti koncentrációnak, másrészt bizonyos értékhatár alatt nem tiltja állami támogatás nyújtását kis szervezeteknek.

Ezzel párhuzamosan a szervezeti súlyképzést is a magyar gazdaság egyik leglényegesebb kihívásának, a foglalkoztatottság növelésének a szolgálatába célszerú állítani. Nemcsak a munkanélküliek felszívásáról és az újonnan munkába álló generációk foglalkoztatásáról van szó, hanem adott esetben a kényszervállalkozások, illetve nem hatékonyan működő kis- és középvállalatok megszűnésével felszabaduló munkaerő elhelyezéséről is.

Az utóbbi években az egymást követő magyar kormányok nem vették figyelembe a bér- és jövedelempolitikában a vállalatszervezeti rendszer sajátosságait. A minimálbér emelése ugyanis nehéz helyzetbe hozta, illetve hozza a kényszervállalkozásokat, illetve a piaci alapon működő kis és közepes méretű vállalkozásokat. Mivel ezek a vállalkozások nem, vagy nehezen tudják kitermelni a minimálbért és járulékait, ezért a minimálbér emelése, illetve tágabb értelemben minden fajta béremelés a fekete gazdaságba való visszavonulást ösztönzi ebben a vállalati szegmensben. A minimálbér emelése és a fekete gazdaság visszaszorítása, illetve kifehérítése tehát ellentmondásban van egymással. Nem ez az egyetlen ellentmondás. Az Európai Unióhoz hasonlóan Magyarországon sem volt összhangban a kis- és középvállalatokat preferáló retorika a tényleges gazdaságpolitikai döntésekkel abból a szempontból, hogy a vállalkozásösztönzésre előirányzott és fordított különféle pénzügyi forrásoknak jóval nagyobb hányada jutott nagyvállalatokra, mint a kis- és középvállalati szektorra.

A kis- és középvállalkozásokat ösztönző gazdaságpolitika középpontjába a közvetlen export, tágabb értelemben a beszállítói kapcsolatok ösztönzését célszerű állítani.

A kis és közepes méretű együttmúködő partnerek és beszállítók termékei, illetve szolgáltatásai iránti keresletet hosszú távon két olyan tényező fogja táplálni, amely eddig talán kevésbé volt az érdeklődés középpontjában. Az egyik tényező a nemzetközi versenyképesség lokális és a globális meghatározóiban, azok egymáshoz viszonyított arányaiban bekövetkezett változás. A szakirodalomban, azon belül is elsősorban Michael E. Porter műveiben mindinkább teret nyer az a felismerés, hogy a globális verseny alapegységei nem annyira az elkülönült vállalatok, hanem inkább a vállalatcsoportok és különféle stratégiai szövetségek és üzleti hálózatok. Ezek pedig szorosan kapcsolódnak a helyi gazdasághoz, illetve a tágan értelmezett helyi üzleti környezethez, beleértve a non-profit intézményeket és a közigazgatást is, nem utolsó sorban azért, mert a tapasztalatok alapján a globalizáció erősödése ellenére a tartós versenyelőnyök forrásai a helyi üzleti környezetben találhatók.

A másik, az előbbivel összefüggő tényező a helyi környezethez kötődő hálózatok egyik legsikeresebb formája a klaszter (a szó egyébként térbeli csomó- 
sodást, csoportosulást, fürtösödést jelent), ami a globális verseny kihívásaira adott válasznak is tekinthető (Lengyel Imre, 2002). A klaszterek adott iparág nagy volumenű összeszerelést vagy tömegszerű termelést folytató kulcsvállalataira épülnek, amelyek jellemzően exportálnak, illetve a múködésük körén kívüli régión túl fekvő piacokon értékesítenek. E nagy kulcsvállalatok tevékenységét segítik a helyi erőforrásokra és infrastruktúrára támaszkodó beszállítók és egyéb együttműködő partnerek.

A kis és közepes méretű együttműködő partnerek és beszállítók tartós fennmaradásának, életképességének kedvez a közösségi verseny- és támogatáspolitika. Ennek súlypontja az utóbbi időben eltolódott a közvetlen formákról a közvetett formákra. A nagyvállalatoknak a beszerzési források, illetve az értékesítési piacok közvetlen ellenőrzésére irányuló vertikális integrációs törekvéseit egyre kevésbé nézi jó szemmel a közösségi versenyhatóság. A klaszterek szerveződése viszont megengedett, sőt támogatott, mert a vertikális integrációnál lazább szerveződés, ahol a részt vevők önállósága is fennmarad. Ezzel párhuzamosan egyre kevesebb a lehetőség a vállalatok közvetlen megsegítésére vagy ösztönzésére, legalább is a nagyvállalati szférában. Ugyanakkor, egyrészt a tágan értelmezett üzleti infrastruktúra fejlesztéséhez, másrészt a kis és közepes méretű vállalatoknak nyújtott állami támogatások nem torzítják el az EU egységes belső piacán a versenyt, és nem is fenyegetnek azzal. A klaszterekbe való szerveződés ezért a lehetséges - nemzeti és közösségi - állami támogatások felhasználásának optimális formája, illetve eszköze lehet.

Magyarországon a klaszeterek kialakulása még a kezdeteknél tart. A meglévő klaszterek (például az autóiparban) jórészt formális szerveződéseknek tűnnek, további lépésekre van szükség az együttműködés tartalmának fejlesztése terén. Nemzetközi tapasztalatok garmadája utal arra, hogy a klasztereket felülről nem lehet, nem érdemes létrehozni. A hosszú távon fenntartható klaszterek létrejöttének a feltétele a józan belátás, az, hogy a potenciális résztvevők, a nagy, illetve a kis és a közepes méretủ vállalatokat, sőt a helyi intézményeket, közigazgatást is beleértve, felismerik közös üzleti érdekeiket, és közösen lépnek azok érvényesítéséért.

A tapasztalatok alapján nemcsak a klaszterek kialakulása, hanem azt megelőzően a beszállítóvá válás hosszabb ideig tartó folyamat, amelyben a külföldi nagyvállalatok nagyszámú szempont alapján vizsgálják a potenciális beszállítókat. A Nyugat-Európában kialakult gyakorlattól eltéróen Magyarországon nincsenek a kis és közepes méretű vállalati szektornak hatékony érdekképviseleti intézményei, ezáltal érdekérvényesíto képessége is kisebb. Ezt a gyengeséget az államnak célszerủ ellensúlyoznia. Ennek egyik eszköze a nemzeti versenyjog vonatkozó rendelkezéseinek az érvényesítése, elsősorban annak a megakadályozása, hogy a külföldi nagyvállalatok következmények nélkül visszaélhessenek gazdasági erőfölényükkel.

A gazdaságpolitika további feladata a magyar tulajdonú vállalkozások segítése az EU egységes belső piacába való integrálódásban. A közösségi vívmányokon belül nagyon sok olyan elöírás, napi gyakorlat, együttmüködési forma stb. van (műszaki szabványok, minőségirányítási rendszerek, a tartós vállalati életképesség bizonyítása, termék-megfelelési eljárások, a CE terméktanúsítási jelölés, szakmai felelősségbiztosítás stb.), amely nem ölt jogszabályi formát, de amelyet versenyképességük biztosítása érdekében át kellett, illetve át kell venniük a magyar gazdasági szereplőknek.

A közösségi joganyagban is nagyon sok olyan, a biztonságot és a környezet védelmét szolgáló jogszabály van, amelynek alkalmazása nem merül ki abban, hogy az arra épülő magyar jogszabály megjelenik a Magyar Közlönyben. Ezek a jogszabályok egyrészt specifikus jellegűek, azaz céljuk egy-egy iparág, ágazat vagy szakágazat termelési eljárásai és termékei által okozott szennyezés mérséklése. Másrészt van néhány olyan környezetvédelmi jogszabály, amelynek célja általában az ipari szennyezés csökkentése. E jogszabályok közös jellemzője, hogy alkalmazásukhoz a vállalati szférának, sőt sok esetben a központi államigazgatásnak és az önkormányzatoknak is rendelkezniük kell megfelelő képességekkel és anyagi eszközökkel.

A közösségi szabványok, a különféle minőségbiztosítási rendszerek átvétele, a termékfelelősség tanúsítása és a szakmai felelősségbiztosítás megléte önmagában nem javítja a magyar vállalatok nemzetközi és hazai versenyképességét, nem teremt versenyelőnyöket, hanem csak versenyhátrányait szünteti meg. (Azt nem lehet kizárni, hogy amíg nem válik általánossá, addig a magyar piacon versenyelőnyt eredményez például a minőségbiztosítási rendszerek megléte.) Mindennek az elmulasztása viszont rontja a vállalati versenyképességet, illetve gyakran akadályozza magát a piacra jutást. E rendszerek átvétele tehát a versenyképesség szükséges, de nem elégséges feltétele. Közösségi tendereken is csak olyan vállalatok indulhatnak, amelyek eleget tesznek az említett feltételeknek. Az ezzel kapcsolatos költségeket hosszú távú beruházásként célszerü felfogni, amely ahhoz szükséges, hogy a magyar vállalatok kiaknázhassák az 
egységes belső piac által teremtett lehetőségeket és előnyöket. Az EU-csatlakozásra való felkészülés költségei tehát egyébként versenyképes vállalatok esetében hosszú távon megtérülnek.

Illúzió lenne azt hinni, hogy az EU-csatlakozás, illetve az egységes belső piacba integrálódás nélkül meg lehetne takarítani az említett, a magyar vállalati szféra versenyhátrányait kiküszöbölő vagy mérséklő alkalmazkodás költségeit. Egyrészt a globalizálódó világgazdaságban erre egyre kevesebb a lehetőség. A belső piac szabályrendszere valamilyen formában előbb vagy utóbb megjelenik a globális szabályozásban is, legfeljebb valamivel gyengébb formában. Másrészt az Európai Unió Magyarországnak hagyományosan a legnagyobb exportpiaca, így a hozzá való alkalmazkodás elkerülhetetlen. Az EU-csatlakozás felgyorsította és intézményesítette ezt az egyébként is kikerülhetetlen folyamatot.

Az EU-csatlakozás a vállalati szféra számára rövid távon inkább alkalmazkodási kényszer, nem kevés költséggel, miközben az abból származó előnyök hosszabb távon bontakoznak ki. Az EU-csatlakozást inkább lehetőségként célszerű felfogni, amelynek kihasználása a vállalatokon múlik.

E követelményeknek a külföldi részvétellel működő nagyvállalatok, azok közül is mindenekelőtt azok tesznek eleget, amelyek külföldi tulajdonosának székhelye az Európai Unió valamelyik tagállama. E vállalati kör számára semmilyen gondot nem okozott az EU-csatlakozás. Az új szabályozási környezetre ezek a cégek az anyavállalat segítségével készültek fel.

Az EU-csatlakozás a tisztán magyar tulajdonban lévő nagy, főként pedig közepes és kisvállalatok számára jelentett kihívást. A magyar tulajdonú cégek közül az olyan nagyvállalatok, mint például a MOL Rt., a Richter Gedeon Rt., a BorsdodChem Rt., a TVK Rt., a Dunaferr Rt. stb. saját pénzügyi és humán erőforrásaira támaszkodva képes volt felkészülni az EUcsatlakozásra. Ráadásul az ún. globalizált iparágakban működő nagyvállalatoknak az EU-csatlakozástól függetlenül is eleget kellett tenniük az említett követelményeknek. A kis- és a közepes méretű vállalatokból álló kör az, amely leginkább segítségre szorult, sőt még most is szorul az EU-csatlakozáshoz, mert saját pénz- és humántőke-forrásaik nem elegendőek a felkészüléshez, a csatlakozással előállt új szabályozási feltételekhez való alkalmazkodáshoz.

Az Európai Unió tagországai GDP-jük 10-12 százalékának megfelelő összegeket fordítanak államiközületi beszerzésekre. Naponta átlagosan 400-500 új tenderfelhívást tesznek közzé az Európai Unió országaiban, azaz igen jelentős piacról van szó, ahol ugyan a közbeszerzési eljárásból adódóan erős a verseny, ezt viszont kárpótolja a nemfizetési kockázat hiánya, vagy legalábbis nagyon minimális valószínűsége. A magyar vállalatok stratégiájának hosszú távon növekvő fontosságú eleme a tagállamok állami-közületi szektorában kiírt tendereken való részvétel.

Az Európai Megállapodás értelmében magyar vállalatok a nemzeti elbánás elve alapján 1994 óta vehetnek részt közösségi tagországok közbeszerzési pályázatain. Magyarországnak 2004. február 1-től kell az Európai Unióban bejegyzett vállalatoknak a hazaiakkal megegyező feltételeket biztosítania, azaz meg kellett szüntetni a hazai vállalkozóknak korábban biztosított kedvezményeket, ami erősíti a versenyt. Ráadásul a csatlakozási okmány hatályba lépésével az új EUtagállamok vállalatai is megjelenhetnek a magyar közbeszerzési piacon, tovább erősítve a versenyt. A közösségi közbeszerzési piacon a kis és közepes méretű magyar iparvállalatok megjelenési lehetőségei a legkedvezőbbek.

A Közösség alapelveinek (diszkriminációmentesség, egyenlő elbánás stb.), közösségi versenyjog és a közbeszerzésekre vonatkozó közösségi jogszabályok betűjének és szellemének ellentmond minden olyan, az utóbbi időben felszínre került törekvés, amely mesterségesen előnyben kívánja részesíteni a hazai vállalkozásokat a közbeszerzési pályázatokon. ( Például, hogy a hazai vállalkozások aránya 20-ról 80 százalékra emelkedjen a közbeszerzési pályázatokban.) Ezt a célkitűzést jogi úton nem lehet érvényesíteni, hanem csak közgazdasági eszközökkel, közvetetten lehet közelíteni hozzá a hazai vállalati szféra versenyképességének javításával. A cél egyébként sem valamilyen arány elérése kell, hogy legyen, hanem a magyar vállalatok versenyképességének javítása. A javuló versenyképesség előbb-utóbb a hazai közbeszerzési pályázatok eredményeiben is kifejezésre fog jutni.

\section{Vállalati bérterhek és versenyképesség}

Az üzleti szféra egyik legnagyobb, nagy számú vállalkozásnak a legnagyobb költségétele a bér és bérjárulék. Magyarországnak a nemzetközi munkamegosztásba való erőteljes bekapcsolódása miatt e költségek közvetlen összemérődnek a nemzetközi piacokon.

A Bécsi Nemzetközi Összehasonlítások Intézete adatai szerint a 2002. és 2003. évi magyarországi béremelések átrendezték az euróban kifejezett havi átlagos bruttó bérek regionális rangsorát. Amíg 2001-ben Szlovénia mellett még Lengyelországban és Csehországban is magasabb volt az átlagos bruttó havi munkabér, mint nálunk, addig 2004-ben Magyarország 
megelőzte két versenytársát. Magyarország korábbi bérelőnyei tehát lemorzsolódtak, Szlovénia után itt a legmagasabb az átlagos bruttó havi munkabér.

Az átlagos bruttó havi munkabérek nagyságából önmagában, a munkabért terhelő járulékok nélkül nem lehet messzemenő következtetéseket levonni a nemzetközi versenyképességről a munkaerőköltségek tekintetében. A bért terhelő járulékok alapján Magyarország a közép-európai országok középmezőnyében helyezkedik el. A munkavállaló, valamint a munkáltató által fizetett járulékok (a fix összegúek nélkül, amilyen például az egészségügyi hozzájárulás) nem mutatnak kiugró értéket a régióban (1. táblázat).

1. táblázat

Átlagos havi bruttó bérek (euró)

\begin{tabular}{|l|c|c|r|r|c|}
\hline & 2000 & 2001 & 2002 & 2003 & $2004^{*}$ \\
\hline Magyarország & 337 & 403 & 504 & 541 & 579 \\
\hline Csehország & 382 & 434 & 515 & 531 & 566 \\
\hline Lengyelország & 472 & 557 & 544 & 501 & 538 \\
\hline Szlovákia & 268 & 286 & 316 & 346 & 359 \\
\hline Szlovénia & 935 & 988 & 1041 & 1083 & 1120 \\
\hline
\end{tabular}

Megjegyzés: * előzetes adat

Forrás: Wiener Institut für Internationale Wirtschaftsvergleiche.

A nemzetközi versenyképesség szempontjából azonban nem az összes, hanem a munkaadók által fizetett járulék nagysága a meghatározó. A vállalkozások számára ugyanis nemcsak a munkabér, hanem annak járuléka is költség. E vonatkozásban viszont Magyarország a nemzetközi élmezőnyben foglal helyet, ahol az OECD adatai szerint 2004-ben a munkaadókat terhelő bérjárulék a munkaerőköltség 27 százalékát tette ki. Ez az érték csak Franciaországban volt magasabb, mint nálunk.

Ha az euróban kifejezett havi bruttó átlagbért a munkáltatót terhelő járulékokkal korrigáljuk, akkor a munkaerőköltség havi szinten 2004-ben 1298 euró volt Szlovéniában, 764 euró Csehországban, 747 euró Magyarországon, 651 euró Lengyelországban és 495 euró Szlovákiában. Az átlagos bruttó havi bérekhez képest változott a sorrend, Magyarország helyet cserélt Csehországgal. A magasabb munkáltatói járulékok miatt a havi átlagos munkaerőköltség magasabb Csehországban, mint Magyarországon. Ahhoz, hogy a havi munkaerő-költségekben Magyarország versenyképes legyen Lengyelországgal, a munkáltatókat terhelő járulékokat 29-ről 12 százalékra, azaz 17 százalékkal kellene csökkenteni. Ilyen mértékű csökkentésre nincsenek meg a feltételek, ezért nem is lehet reális cél, főleg rövid távon. Mivel Szlovákiában jóval alacso- nyabb a havi bruttó bér, mint Magyarországon, ezért nem lehet, illetve csak igen nagy áldozatok árán lehet a munkáltatókat terhelő járulékok csökkentésével ellensúlyozni a Szlovákiával szembeni versenyképességi hátrányt a munkaerőköltségekben.

Hangsúlyozni kell, hogy a munkaerőköltségek nagysága és alakulása önmagában nem, hanem kizárólag a termelékenység elért színvonala és változása figyelembevételével ad megbízható képet egy ország nemzetközi versenyképességéről a költségek oldaláról. A termelékenység javulása ugyanis semlegesítheti, sőt ellensúlyozhatja a munkaerőköltségek növekedését.

A munkaadókat terhelő bérjárulékok csökkentése javítja a magyar gazdaság nemzetközi versenyképességét a munkaerőköltségek tekintetében. Ez nem csekély mértékben semlegesítheti vagy akár ellensúlyozhatja az erôs, illetve hosszabb távon (főként reál értelemben, azaz valamilyen árindexszel korrigált) felértékelődő forintnak az exportra gyakorolt kedvezőtlen hatását. A statisztikai adatokból ugyanakkor kitűnik, hogy a bérjárulékoknak csak irreálisan nagy mértékű lefaragásával lehetne olyan mértékű versenyképesség-javulást elérni, hogy az Magyarország helyét is módosítsa fó versenytársaival szemben a nemzetközi rangsorban.

Az egyéb feltételeket változatlanoknak tekintve a munkaadói bérjárulékok visszafogása az áruexport mellett a külföldi működőtőke-beáramlást ösztönözheti elsősorban. A munkaerőköltségek csökkenése növelheti Magyarország vonzerejét a reálszférába befektetni kívánó külföldi vállalatok számára. Ugyanakkor a munkaadói bérjárulék csökkentése a nemzetközi versenyképesség szükséges, de nem elégséges feltétele. A teljesség igénye nélkül megemlíthető, hogy nem célszerű a bérjárulék csökkentésének ösztönző hatásait például a minimálbér erőteljes emelésével semlegesíteni. Ha nem áll rendelkezésre megfelelő képzettségű hazai munkaerő, akkor a külföldi vállalatok az alacsonyabb munkaerőköltségek ellenére sem fognak tömegesen foglalkozásbővítő beruházásokat végrehajtani Magyarországon. Végül semmilyen garancia nincs arra, hogy a járulékcsökkentéssel kapcsolatos megtakarításokat foglalkoztatás-bővítő beruházásokra használják a vállalatok. Mindez arra hívja fel a figyelmet, hogy a bérjárulékok csökkentésének csak átfogó gazdasági stratégiába ágyazva van értelme, csak ebben az esetben javítja a versenyképességet.

\section{Összefoglaló megjegyzések}

A közösségi politikák és jogszabályok nem tartalmaznak határozott explicit célkitűzéseket a szervezeti 
súlyképzésre. Ennek ellenére a versenymechanizmusok minél teljesebb érvényesülését célzó versenypolitika és versenyjog, beleértve az állami támogatások szabályozását, továbbá a vállalkozásösztönzésre vonatkozó közösségi politikák a kis és közepes méretú szervezeteknek kedveznek. A közösségi szintű szabályozás a nemzetállami szintű vállalkozásösztönzéshez ad megfelelő keretfeltételeket, a forrásfedezet oroszlánrészének előteremtését az egyes tagállamokra hagyva. A tagállamok vállalkozásösztönzési politikáinak cél-, eszköz- és intézményrendszere hasonló, összhangban van a közösségi jogszabályokkal és nem kötelező jogszabályi formát öltő dokumentumokkal.

A közösségi szabályozás tág teret hagy a magyar gazdaságpolitika számára a szervezeti súlyképzéshez. A szervezeti súlyképzést az átfogó nemzeti fejlesztésstratégiából lehet és kell levezetni. Ennek hiányában, a magyar gazdaság helyzetének értékelése és a fejlesztésstratégia kívánatosnak tartott prioritása alapján a szervezeti súlyképzést három pillérre célszerú alapozni.

Az első pillér a nemzetgazdasági hatékonyság követelményei, a társadalmi sajátosságok stb. alapján a műszaki-szerkezeti korszerűsödés és a nemzetközi munkamegosztásba való bekapcsolódás hajtóerejét képező nagyvállalati szféra, azon belül a külföldi részesedésű nagyvállalatok képezik. E szféra a fejlesztéspolitika legfőbb célkitűzéseinek (a beruházások és az azokhoz kapcsolódó technológia-transzfer, az export növelésének és új, stabil munkahelyek teremtésének ösztönzése) vállalati méretkategóriától független érvényesítésén túlmenően nem annyira preferálást és támogatást igényel, mint inkább stabil, kiszámítható és átlátható vállalkozásbarát gazdasági és jogi környezetet.

A második pillér a nagy, illetve a kis és közepes cégek közötti vertikális integráció erősítése többek között a beszállítói kapcsolatok és a klaszterek ösztönzése révén. Ennek forrásigénye viszonylag csekély, miközben eredménye - a teljes tényezőtermelékenységhez hasonlóan - számottevő lehet. A gazdasági és politikai racionalitás közötti célkonfliktus feloldása, de legalább is mérséklése érdekében, a kis- és középvállalati szektor foglalkoztatási szerepére tekintettel, politikai okokból gesztus értékű lépésekre van szükség az egész KKVszektorral szemben. Ez némi gazdasági áldozatot a mikro- és az ál- vagy kényszervállalkozások esetében jelent.

A harmadik pillér a kis és középvállalati szektorra vonatkozó differenciált ösztönzési stratégia, amelynek középpontjába a lépéstartási és expanziós képességgel rendelkező, piaci résekben, innovatív termékekkel és szolgáltatásokkal megjelenő, magas hozzáadott értéket realizáló kis- és középvállalati kört célszerű állítani. Az ösztönzés eszközei közé az innovatív kis- és kö- zépvállalatok $\mathrm{K}+\mathrm{F}$ tevékenységének támogatása, a tőkeellátás és a finanszírozás más forrásainak javítása, a klaszterképződés ösztönzése és támogatása, a külpiaci infrastruktúra erősítése tartozik. Döntően ennek a szegmensnek az eredményein múlik a magyar gazdaság követő jellegének módosulása, illetve a követési távolság csökkenése.

A második és a harmadik pillérnek a közvetlen és a közvetett, azaz beszállítókon keresztül történő exportot kell ösztönöznie. E pillér része kell, hogy legyen a hazai tulajdonú kis és közepes méretű vállalatok egységes belső piacba való integrálódásának támogatása, kormányzati eszközökkel történő segítése.

A szervezeti súlyképzésre vonatkozó, három pillérre támaszkodó stratégia nem csekély mértékben járul hozzá a fekete és szürke gazdaság kifehérítéséhez és a reálszférának az euró bevezetésével kapcsolatos esetleges versenyhátrányai mérsékléséhez. Célszerű és kívánatos a szervezeti súlyképzés követelményeit figyelembe venni a fekete, illetve a szürke gazdaság kifehérítésében, az euró bevezetésének ütemezésében, valamint a bér- és adópolitikában. A minimálbér poltikai és más szempontok alapján motivált emelése a fekete és a szürke gazdaság térnyerésének kedvez.

A munkaadókat terhelő bérjárulékok és adók csökkentése a foglalkoztatást ösztönözheti és a relatív nemzetközi versenyképességet javíthatja mindegyik vállalati méretkategóriában, de különösen a nagyvállalatoknál. Mivel a munkabérek képezik a vállalati szféra legjelentősebb költségételét, ezért a munkabérekre rakódó, a vállalatokat terhelő járulékok csökkentésében rejlenek a vállalati versenyképesség javításának legszámottevőbb tartalékai. A járulékcsökkentés feltételeinek megteremtése azonban nem a fejlesztési súlyképzés, hanem a fiskális politika kompetenciájába tartozik. A munkaadói bérjárulékok lefaragása ugyanis mérsékli az államháztartás bevételeit, a kieső bevételek ellentételezéséhez a kiadásokat is vissza kell fogni. El kell kerülni azt, hogy a vállalati bérjárulékok mérséklése által viszszaeső államháztartási bevételeket a vállalati szféra más formában történő adó- és járulékterhelésével (például erőteljes minimálbér-emelés stb.) ellensúlyozzák.

\section{Felhasznált irodalom}

Borbás László (2003): A magyar kis- és középvállalkozások helyzete az EU-csatlakozás után. Megjelent: Pécsi Tudományegyetem Közgazdaságtudományi Kara Regionális Politika és Gazdaságtan Doktori Iskola Évkönyv 2002, Pécs, 2003, 212-235. o.

Érsek Zsolt (2002): Bevezetés a devizapiacokra. Második kiadás. KJK-Kerszöv Jogi és Üzleti Kiadó Kft., Budapest, 2002, 291 o. GKM-OM-IHM (2003): Gazdasági Versenyképesség Operatív Program 2004-2006, Budapest, április 25., 124 oldal. http://www.nfh.gov.hu/xindex2.htm?p=0\&t=2\&i=1904 
Kertesi Gábor - Köllő János (2004): A 2001. évi minimálbéremelés foglalkoztatási következményei. Közgazdasági Szemle, LI. évf. 4. szám, április, 293-324. oldal.

Kozma Ferenc (2001): A kis- és középvállalkozások Magyarországon. Alma Mater (a Budapesti Gazdasági Főiskola Kereskedelmi Vendéglátóipari és Idegenforgalmi Főiskolai Kara folyóirata) 5. szám, 43-51. oldal.

KSH (2004): Magyar statisztikai évkönyv 2003, Központi Statisztikai Hivatal Budapest, 642 oldal.

Lengyel Imre (2002): A klaszterek alapvető jellemzői. Megjelent: Lengyel Imre - Rechnitzer János: A hazai építőipar versenyképességének javítása: klaszterek szerepe a gazdaságfejlesztésben. Régió Art Kiadó, Győr, 2002, 99-124. oldal.

Román Zoltán (2004): A vállalkozás az Európai Unióban és Magyarországon. Európai Tükör, IX. évfolyam, 7. szám, október, 20-65. oldal.

Solt Katalin (2003): Gondolatok az evolúciós közgazdaságtanról és a vállalatelméletről. Megjelent: Meyer Dietmar — Solt
Katalin (szerk.): Evolúciós közgazdaságtan. Tudományos füzetek IV. kötet. Széchenyi István Egyetem Gazdaság- és Társadalomtudományi Intézet, Győr, 2003, 103-117. oldal.

\section{Lábjegyzetek}

Nizzai Szerződés 82. cikk, illetve az azon alapuló 4064/89 (EGK) tanácsi rendelet a koncentráció ellenőrzéséről és az azt módosító 1310/97 (EK) tanácsi rendelet.

Council Decision 2000/819/EC)

A vállalkozássűrűségről lásd többek között: Román Zoltán (2004).

4 Mihályi Péter(2005): Közteherviselés — ma és holnapután. Élet és Irodalom, 2005. szeptember 16., 6.

Szürkegazdaság: ezermilliárdos lyuk az államkasszában. Népszabadság, 2005. december 10., 12. o.

Sokmilliárdos csali befektetőknek. Népszabadság, 2005. július 13., 11. o.

E számunk szerzői:

HAJNAL György, tudományos főmunkatárs, Magyar Közigazgatási Intézet; Dr. LOSONCZ Miklós, kandidátus, GKI Gazdaságkutató Rt.; Dr. BUZÁDY Zoltán, egyetemi docens, Budapesti Corvinus Egyetem; NÉMETHNÉ Dr. PÁL Katalin, kutatásvezető, GKI Gazdaságkutató Rt.; DEÁK István, egyetemi adjunktus, SZTE; LUKOVICS Miklós, PhD hallgató, SZTE; HORÁNSZKY Beáta, okl. gázmérnök, okl. Európa szakértő, egyetemi tanársegéd, Miskolci Egyetem; Dr. SZAKOLCZAI György, professzor emeritus, Általános Vállalkozási Főiskola; Dr. KRISZTIÁN Béla, PhD, egyetemi adjunktus, PTE; RUBÓCZKY István, nyugd. oszt. vez. 